\title{
Çevre Etiği Bağlamında Medyanın Çevre Sorunlarına Yönelik Sorumluluğu: Kırgızistan Gazeteleri Örneği ${ }^{1}$
}

\author{
Gökçe YOĞURTÇU ${ }^{2}$
}

\section{$\ddot{\mathrm{O} z}$}

Doğayı koruma ve onu gelecek nesillere sağlıklı bir şekilde bırakma sorumluluğu, etik değerlerin ve siyasetin kurucu unsurlarından biri haline gelmiştir. Bu sorumluluğun farkına varılması tüm dünya ülkeleri için olduğu gibi Kırgızistan için de önemlidir. Kırgızistan coğrafi konumu gereği çeşitli çevresel riskler altındadır. Bu sorunlara yönelik farkındalık yaratmak ve çevre politikalarına yön vermek açısından medyanın potansiyel bir güç olması beklenmektedir. Bu çalışmanın amacı da Kırgızistan basınının çevre sorunlarına ilişkin halkı bilgilendirme ve farkındalık yaratma sorumluluğuna dikkat çekmektir. Bu amaçla araştırmada, Kırgızistan’daki çevre sorunlarının basına nasıl yansıdığı sorusuna yanıt aranmıştır. Analiz kapsamında Kırgızistan'ın tirajı en yüksek kamu gazetesi olan "Kırgız Tuusu” ve tiraj1 en yüksek özel gazetesi olan "Süper İnfo" gazeteleri örneklem olarak seçilmiştir. Bu gazetelerin internet sitelerinde 1 Temmuz 2019 - 1 Temmuz 2020 tarihleri arasında yer alan çevre sorunlarıyla ilgili toplam 103 haberin içerik analizi yapılmıstır. Elde edilen bulgular; gazetelerin çevre sorunlarına "insan merkezli” yaklaştığını ve çevre haberciliği perspektifinin yetersiz olduğunu göstermektedir.

Anabtar Kelimeler: Çevre Sorunları, Çevre Etiği, Çevre Haberciliği, Kırgızistan.

\section{The Responsibility of Media towards Environmental Problems in the Context of Environmental Ethics: The Case of Kyrgyz Newspapers}

\begin{abstract}
The responsibility to protect nature and leave it to future generations in a healthy way has become one of the founding elements of ethical values and politics. Awareness of this responsibility is important for Kyrgyzstan as it is for all countries in the world. Kyrgyzstan is under various environmental risks due to its geographical location. Media is expected to be a potential force in raising awareness of these issues and directing environmental policies. The aim of this study is to draw attention to the responsibility of the press of Kyrgyzstan to inform the public about environmental problems and to raise awareness. For this purpose, in the research, an answer was sought to the question of how the environmental problems in Kyrgyzstan are reflected in the press. Within the scope of the analysis, "Kyrgyz Tuusu", which is the highest circulation public newspaper in Kyrgyzstan, and "Super Info", the private newspaper with the highest circulation were selected as samples. A content analysis of news on environmental problems published on the websites of these 103 newspapers between July 1, 2019 and July 1, 2020 was conducted. Findings show that newspapers have an anthropocentric approach to environmental problems and that the perspective of environmental journalism is inconclusive.
\end{abstract}

Key Words: Environmental problems, Environmental ethics, Environmental journalism, Kyrgyzstan

\author{
Atıf İçin / Please Cite As: \\ Yoğurtçu, G. (2021). Çevre etiği bağlamında medyanın çevre sorunlarına yönelik sorumluluğu: Kırgızistan \\ gazeteleri örneği. Manas Sosyal Araştırmalar Dergisi, 10(2), 1151-1167.
}

Geliş Tarihi / Received Date: 10.03.2021

Kabul Tarihi / Accepted Date: 23.03.2021

\footnotetext{
1 Bu çalışma, 19-21 Ekim 2019 tarihleri arasında SADAB 4. Sosyal Araştırmalar ve Davranış Bilimleri Sempozyumunda sözlü olarak sunulmuş ve özeti basılmış olan "Framing of News on Environmental Problems in Kyrgyzstan Press" başlıklı bildirinin tamamlayıcısı niteliğindedir. Söz konusu bildiride 2018 yılı haberleri analiz edilmiş olup, bu araştırmada 2019-2020 yılları arası haberlerin analizi yapılmış ve çevre etiği perspektifinden değerlendirilmiştir.

2 Dr. Öğretim Üyesi - Kırgızistan-Türkiye Manas Üniversitesi İletişim Fakültesi, gokce.yogurtcu@manas.edu.kg

(iD ORCID: 0000-0002-2404-3908
} 


\section{Giriş}

Çağımızda çevre sorunları, tüm canlı yaşamını ve doğayı tehdit edici boyutlara ulaşmıştır. Zamanında ve etkili önlem alınmaması durumunda dünyayı daha ciddi yaşamsal sorunlar beklemekte ve bu yöndeki endişeler artmaktadır. Çevre sorunlarının yaşamlarımız üzerindeki etkisi ve nasıl düzeltilebileceği konusundaki tartışma alanları da bu endişelere koşut olarak genişlemektedir.

Dünyamızı tehdit eden çevre sorunlarına baktığımızda; özellikle küresel ısınmaya bağlı karşılaşılan sorunlar dikkat çekmektedir. Küresel ssınmanın beklenen sonuçlanı, yükselen deniz seviyesine bağlı olarak dünyanın bazı yaşam alanlarının sular altında kalması, çölleşme, hastalıkların yayılması, kıtlık, iklim değişikliğine bağlı doğal afetler, kitlesel göç dalgaları ve kaynakların azalmasına bağlı jeopolitik istikrarsızlıklardır (Giddens, 2012, s. 1009-1010). Bu sorunların yanı sıra çevre-hava-su kirliliği, yağmur ormanlarının yıkımı gibi sorunlar da belirgin bir şekilde artış göstermektedir. Doğal kaynakların sürekli bozulması ve tükenmesi ihtimali, nüfus artışı ile birlikte artmaktadır. Gelecek nesilleri tehdit edecek zehirli atıklar birikmeye devam etmekte ve bazı nükleer atıkların on binlerce yll ölümcül olmaya devam edeceği bilinmektedir. Çevreye yönelik müdahalelerin bir kısmı artan dünya nüfusu ve yoksulluk için gıda temini anlamına gelse de yıkıcı sonuçları çok daha fazla olabilmektedir (Des Jardins, 2013, s. 6-7). Gıda sorunu bağlamında doğal kaynakların sömürülmesinin yanı sıra türler arasında genlerin karıştırılması, hayvanların stres ve aciya maruz birakılması gibi etik sorunlar da artmaya devam etmektedir.

Bilim insanları bu çevre sorunlarının, insanın doğa ile olan hatalı ilişkilerinin sonucu olduğunu ortaya koymaktadır. Zamanla birçok sorunun bileșeni bu farkındalığı arttırmıș ve bilim insanlarını bu yönde araştırmalar yapmaya yöneltmiştir (Attfield, 1991, s. 1). Doğa bilimcileri dünya sisteminin fiziksel süreçlerindeki değişiklikleri dikkate alarak yaptıkları çalışmalar sonucu çevre sorunlarının antropojenik olduğunu bulgulamıştır. Bu bulgular çevre sorunlarına yönelik insan etkisi ölçeğinin haritalanması sonucu elde edilmiştir. Ölçek bulguları, kara ve su ekosistemlerinin önemli bir değişim geçirdiğini ve dünyanın daha ciddi ekolojik değişimlerin eşiğinde olduğunu göstermektedir (Longo, Clausen ve Clark, 2015, s. 16). $\mathrm{Bu}$ sorunların gittikçe artan aciliyeti karşısında, insanın doğa ile olan ilişkilerini gözden geçirme zorunluluğu doğmuş (Ferry, 2000, s. 111), doğayı koruma ve onu gelecek kuşaklara sağlıklı bir şekilde bırakma sorumluluğu etik değerlerin ve siyasetin kurucu ilkelerinden biri haline gelmiştir (Ferry, 2000, s. 122). Bu bağlamda "endüstriyel kapitalizm", "ekonomik kalkınma" ve "insan merkezli hak kavrayışı" gibi klasik ekonomi-politik ve etik tutumlar sorgulanmaya başlamıştır (Siebert, 2020; Ortiz, 2020; Sparks, Kurki ve Stucki, 2020).

$\mathrm{Bu}$ sorgulamalar ve çözüm arayışları tüm dünyayı olduğu gibi Kırgızistan toplumunu da ilgilendirmektedir. Kırgızistan coğrafi konumu gereği çeşitli çevresel riskler altındadır. Özellikle madenlerin yol açtı̆̆ çevre tahribatı, hava kirliliğinin ciddi düzeydeki artışı, nesli tükenmekte olan hayvanların avlanması, temiz su kaynaklarının azalması gibi sorunlar dikkat çekici düzeydedir. Bu sorunlara karşı farkındalık yaratmak ve çevre politikalarına yön vermek açısından medyanın sorumluluk sahibi olması beklenmektedir. Çünkü insanların çevre sorunlarına ilişkin tutumları, bu sorunları en aza indirmek için potansiyel sosyal değişikliklere yol açabilmektedir. Nitekim dünyanın farklı bölgelerindeki deneyimler, çevresel sorunların kamusal alanda daha sık gündeme gelmesinin sosyal direniş hareketlerini genişlettiğini göstermektedir (Tong, 2014; Evans, Schofer ve Hironaka, 2000).

Kırgizistan toplumunun, çevre risklerinin azaltılabileceği bir topluma doğru gelişmesi için de medyada çevre sorunlarına yönelik farkındalığın güçlendirilmesi önemlidir. Bu önemden hareketle araştırmada, Kırgızistan'daki çevre sorunlarının basına nasıl yansıdığı ve çevre haberlerinin nasıl çerçevelendiği incelenmektedir. Çalışmada öncelikle çevre sorunlarının teorik arka plan bağlamı üzerinde durulmakta, daha sonra incelenen gazetelerdeki çevre konulu haberlerin içerik analizi bulguları değerlendirilmektedir.

\section{Çevre Etiği Perspektifinden Çevre Sorunlarına Bakış}

Çağdaş ekolojinin temeli mevcut çevre hasarlarını tespit etmek, gelecek sorunları öngörmek ve gerekli tedbirleri almak üzerine kuruludur. Bu öngörüler, bölgesel ve küresel kapsamda ölçülebilen olgusal ve ampirik verilere dayanmaktadır. Doğaya yönelik yapılan işlemlerin genellikle birçok yan etkisi vardır ve bu etkileri ampirik olarak ölçmek her zaman kolay değildir. Ancak bu müdahalelerin yan etkilerinin olduğu gerçeğini göz önünde bulundurmak için sorunları 'ekolojik' olarak tespit etmek önemlidir. Bu tespitler, sorunların tanınmasını, nedenlere ve olası çözümlere ilişkin ölçüme dayalı bir inceleme alanı açılmasını sağlamaktadır (Attfield, 1991, s.4). Bu bağlamda birbiriyle ilişskili çevre sorunları ağının; nüfus artışından, 
refahtan, teknolojiden, kapitalizmden ve ekonomik büyümeden kaynaklandığını gösteren birçok veri vardır (Attfield, 1991, s. 15-16).

Bu verilerin ortak noktası "büyüme sınırları" tezine işaret etmektedir. 1972'de yayımlanan Roma Derneği Raporunda (The Limits to Growth) bilgisayar modellemeleri ile yap1lan incelemeler sonucunda "nüfustaki, sanayileşmedeki, kirlilikteki, besin üretimindeki ve kaynak azalmasındaki" mevcut büyüme düzeylerinin sürdürülemezliğine ilk kez işaret edilmiştir (Giddens, 2012, s. 993). Bu faktörlerin büyümesine yönelik sınırlara ise önümüzdeki yüz y1l içinde ulaş1lacağ1 öngörülmektedir (Longo, Clausen, and Clark, 2015, s.19). Bu doğrultuda ekonomik büyüme yerine "sürdürülebilir kalkınma" kavramı öne çıkmaya başlamıştır. Bu kavram ilk kez Birleşmiş Milletlerin önerisiyle başlatılan “Ortak Geleceğimiz” başlıklı 1987 tarihli raporda ortaya atılmıştır. Rapor, yeryüzü kaynaklarının mevcut eğilimlerin devam etmesi durumunda sürdürülemez olduğunu ileri sürmektedir (Giddens, 2012, s. 994).

$\mathrm{Bu}$ tespitler doğrultusunda çevre sorunlarına çözüm bulma ihtiyacı, bir dizi uluslararası anlaşmayı (Montreal ve Kyoto protokolleri gibi) gündeme getirmiştir (Smith, 2011, s. 194). Bu tür anlaşmalar “ekolojik buzdağı”nın sadece görünen kısmı olarak değerlendirilse de insan kaynaklı çevre sorunlarına bir çeşit sosyo-politik yanıt durumundadır. Bu yanıtlar, çeşitli sosyal 'aktörleri' (çevreci sivil toplum örgütlerini ve ulusötesi şirketleri) de kapsayacak şekilde, ekolojik hasarın önlenmesine ve yeni çevresel yönetim biçimlerinin geliştirilmesine hizmet edebilmektedir (Smith, 2011, s. 195). Yeni çevresel yönetim biçimleri, "yeşil devlet egemenliğinin” artan bir şekilde savunulmasına yol açmıştır. Yeşil devlet uygulamaları küresel sermayenin baskılarına karşı çevresel yıkıma duyarlı olmayı ve daha sürdürülebilir bir toplum adına bazı müdahaleleri önermektedir (Smith, 2011, s. 199).

Bu bağlamda çevre politikalarına yön verecek birçok farklı yaklaşım ve etik öğreti tartışılmaktadır. Bu yaklaşımları, genel olarak "insan merkezci" ve "insan merkezci olmayan" (çevre merkezci, canlı merkezci, derin ekoloji gibi) yaklaşımlar olarak ayırabiliyoruz. Bu yaklaşımların pratikteki en temel amacı çevreyi korumayı amaçlayan sosyal politikalar için etik temeller sağlamaktır. 1970’lerden beri artan çevre tartışmaları; bu temelleri oluşturmak için çevre etiği, toprak etiği ve hayvan etiğini de kapsayacak şekilde birçok konu ve problemi ele almaya başlamıştır. Bu tartışmalar her şeyden önce insanın doğal çevresine karşı ödev ve yükümlülükleri olduğu kabulüne dayanmaktadır. Burada temel soru; insanın doğal çevreye karşı yükümlülüklerinin günümüz insanı için mi, gelecek nesiller için mi yoksa doğadaki tüm canlılar için mi geçerli olacağı sorusudur (Cevizci, 2013, s. 122).

Bu bağlamda "insan merkezci” ana akım yaklaşım, “insanın çevreye karşı yükümlülüklerinin, gezegenin bugünkü ve gelecekteki sakinlerine karşı olan ödevlerimizden çıktığını savunur. Bu ödev bilinci, ahlaki ilginin kapsamını insanın yine merkezde olması koşuluyla, gelecek kuşakları ve diğer canlıları da kapsayacak şekilde" genişletmeye çalışır (Cevizci, 2013, s. 123). Ancak burada insan-doğa ilişkilerinde “özsel iyi” ile "araçsal iyi” arasında bir ayrım yapılır. İnsan asli ve özsel değere sahip görülürken, diğer bütün canlılar araçsal değerleri üzerinden tanımlanır. Dolayısıyla doğayı koruma ve tahrip etmeme gibi ödevlerimiz, insanın refah ve mutluluğu için görülür (Cevizci, 2013, s. 123).

Bu araçsal değer algısı, çevre sorunlarının zaten kökensel nedeni olduğu için çözüme yönelik işlevi tartışmalıdır. Özellikle Descartes’in izinde "ben” üzerinden yaşamı anlamaya çalışan modern insan, doğayla ve insan olmayan canlılarla kurduğu ilişkide çok daha antroposentrik bir değer algisı oluşturmuştur. Bu değer algısı içinde doğa ve insan dışı canlılar etik, siyaset ve hak konusu olabilecekleri bir konum içinde yer alamamıslardır (Mutlu, 2020, s. 512). Doğaya karşı tavrımızın sadece insanların çıkarları ve ihtiyaçları üzerinden belirlenemeyeceğini savunarak bu değer algısına karşı çıkan görüşler, insanın doğaya karş1 yıkı1c1 tavrını görebilmesi için kendisini doğadan üstün görme tutumundan vazgeçmesi gerektiğini vurgular. Çünkü insanın çevreye hükmetme iradesini temsil eden "insan merkezcilik", insan dışı yaşamı olduğu kadar insan dünyasını da tehdit eder hale gelmiştir (De Jonge, 2016). Bu çerçevede, insan dişındaki canlıların ve doğanın da içsel değerlerini tartışan "çevre merkezci” ve "canlı merkezci” yaklaşım, bir bütün olarak dünyanın kötü durumuyla ilgilenmek için ekolojik bir vicdan geliştirmemiz adına daha doğru ve adil bir yol sunmaktadir.

Söz konusu çevre merkezci etik anlayışın yolunu açan kişi, toprak etiğiyle 1980’lerden itibaren dikkati çeken Aldo Leopold'dur. Leopold “A Land Ethics” (1987) başlıklı çalışmasında; etiğin "insanları olduğu kadar, hayvanları, bitkileri, dağları taşları ve nehirleri” de içine alacak şekilde genişletilmesi çağrısında bulunur (Leopold, 1987, s. 203-204). Bu genişlemenin ekolojik bir zorunluluk olduğunu dile getirir. Çünkü modernitenin araçsal aklı, doğanın ve toplumsal hayatın tahakküm altına alınmasına neden olmuştur. 
Yeryüzü böylelikle bir mülkiyet, kazanç alanına dönüşmüştür. Ancak insanın kendini "toprağın fatihi” görme rolünün, sonunda kendi kendini mağlup ettiği görülmüştür. Leopold’e göre yeryüzü araçsal değerden daha fazlasına sahiptir. Tüm "toprak topluluğu” varllğını sürdürme hakkına sahiptir ve insan bu topluluk içinde ayrıcalıklı bir konuma sahip değildir, toprağın diğer sakinleri gibi ekolojik bir yurttaştır. İçüdüleri insanı o topluluktaki yeri için rekabet etmeye sevk etse de ahlakı onu işbirliği yapmaya teşvik eder. Bu işbirliği sosyal vicdanın insandan toprağa doğru genişlemesini ve kişisel çıkarların biyotik topluluğun refah ve iyiliğini hesaba katacak bir biçimde sınırlanmasını talep etmektedir (Leopold, 1987, s. 204-205).

Leopold'un bu bütüncül ve deontolojik öğretisini, biyosferik eşitlikçiliğin savunusunu yaparak genişleten yaklaşım ise "derin ekoloji” (deep ecology) olmuştur. 20.yy'n üç önemli küresel hareketinden (sosyal adalet, dünya barışı ve ekolojik sorumluluk) biri olarak tanımlanan "derin ekoloji”" ifadesi ilk olarak Arne Naess tarafindan kullanılmıştır. Naess (2008), "sı̆ /yüzeysel ekoloji” ile "derin ekoloji” arasında ayrım yapmışır (Drengson, 2008, s. 24-25). Naess'e göre sı̆̆/yüzeysel yaklaşım, çevre sorunlarına insan merkezci bir perspektiften bakar ve çevre sorunlarının önlenmesini gelişmiş ülkelerin doğadan daha fazla faydalanabilmesi için ister. Derin ekoloji ise uzak gelecek nesilleri, Üçüncü Dünyayı, insan olmayan türleri ve bir bütün olarak biyosferi dikkate alır ve bunların hepsini bağımsız ahlaki bir özne olarak görür. Örneğin, 'koruma' terimi her iki hareketin endişelerine ve faaliyetlerine uygulandığında; sığ/yüzeysel ekoloji hareketi insanın faydalandığı temel kaynakları korumaya atıfta bulunurken; derin ekoloji hareketi, insan olmayan türleri ve vahşi yaşam alanlarını sadece kaynak olarak görmez ve doğal ekosistemin bütüncül dengesini korumak için çaba gösterir (Attfield 1991, s. 3-4).

Bu bütüncül dengenin korunması için derin insani kaygıların yansıması olan "derin sorgulama" gerekir. Derin sorgulama, ekolojik uyum için insan merkezci egemen dünya görüşünün yapıbozumuna giden yoldur. Bu yolda, doğadaki yerimizle ve benliğin doğasıyla ilgili sorular sorarız. Bu soruların cevabı, "tüm yaşamın temelde bir olduğu", "tüm organizmaların içsel değeri olduğu" ve bu değerin "kendini gerçekleştirme" ile mümkün olduğu gerçeğine dayanır (De Jonge, 2016, s. 35). Kendini gerçekleştirme, bize en yakın olanlara hissettiğimiz ilginin diğer varlıklara nasıl uzanabileceğini göstermek için, benliğin doğası dâhil, doğanın doğasını anlamaya yönelik bir taahhüt gerektirir (De Jonge, 2016, s. 58). Bu kavrayışta 'doğa', tüm varlıkların paylaştığı temel veya içsel bir niteliği temsil eder. Doğa bu anlamda evrensel bir 'benliğgi' ifade eder ve bu sadece bizim içsel doğamızı değil, diğer tüm varlıkların doğasını da karakterize eder (De Jonge, 2016, s. 62). Dolayısıyla kendini gerçekleştirme, tüm ekosisteme tanınan bir haktır. Biyosferdeki herşeyin yaşama, gelişme ve kendini gerçekleştirmeye eşit derecede hakkı vardır. Bunu mümkün kılacak şey insanın doğayla özdeşleşmesi ve öz-çıkara dayalı dar, bencil benlik algısının ötesine geçip, bütüncül bir 'Benlik' geliştirebilmesine bağlıdır (Devall and Sessions, 1985, s. 67-68). Bu doğrultuda Naess, insan merkezli değerler dünyasının neden olduğu acıları ve yanlışları dile getirerek; tüm canlı varlıkların içsel değerini tanıyan ilkeler önermiştir. Bu ilkeler, tüm varlıkların içsel değerine saygıyı vurgulayarak her türlü biyolojik ve kültürel çeşitliliğge değer verilmesini önermekte ve bu ilkeleri kabul edenleri sorumlu davranmaları konusunda yükümlü görmektedir (Naess, 1986, s. 14).

Biyosferik eşitlikçilik ve tüm canlı varlıkların içsel değerinin tartışıldığı başka bir alan da hayvan etiğidir. Bu yolu açanların başında Peter Singer ve Tom Regan gelir. Bu iki düşünür de hayvanların ahlaki bir ilginin konusu olmaları gerektiğini savunur. Peter Singer "Hayvan Özgürleşmesi” (2005) adlı eserinde insanların, insan dışı hayvanlara nasıl davranmaları gerektiği sorununu ele alır. Kendimizden başka türlerin üyelerine karşı yaklaşımlarımızın, ırk ve cinsiyet kaynaklı ayrımcılık kadar sorunlu olduğunu açıklamaya girişir (Singer, 2005, s. 34). Bu bağlamda Singer, çıkarları her ne olursa olsun, benzer ilgi ve çıkarlara sahip bütün canlıları aynı ahlaki ilgiye layık görür (Singer, 2005, s. 31). Ancak çıkarların eşit şekilde önemsenmesiyle, eşit muamele görmesi arasında ayrım yapar. Çünkü özbilinç ve bellek gibi insanların zihinsel yetilerinin önem arz ettiği pek çok alan vardır. Bu farklılıklar insanların hayvanlardan daha fazla acı çekme ihtimalini düşündürebilir. Dolayısıyla hayvanlarla insanların çıkarları çatıştı̆̆ında eşitlik ilkesi her zaman yol gösterici olmaz (Singer, 2015, s. 90-91). Bu noktada belirleyici olan daha çok yarar ilkesidir. Yarar ilkesi, genel olarak dünya üzerindeki acı ve ıstırabın azalmasını ve refahın artmasını gözeten ilkeleri temel alır. Sözgelimi hayvanların deney ve gida üretimi amacıyla öldürülmelerinin yol açtı̆̆ acı, sağladığ1 iddia edilen faydayı fazlasıyla aşmış durumdadır. Birçok keyfi öldürmenin, insanların acılarını dindirmek amaçlı olmadı̆̆ı da açıktır. İnsanların çıkarlarının hayvanlar kadar etkilenmeyeceği durumlarda bu acılara izin verilemez (Singer, 2015, s. 97). Bu acılara karşı çıkmanın ardında yatan gerekçe duygusal değildir, temel ahlaksal ilkelerdir. Dolayısıyla insanların, insan dışı hayvanları acımasızca sömürmesine son verecek değişikliklerin yapılması ahlaki bir zorunluluktur (Singer, 2005, s. 32-34). 
Bu ahlaki zorunluluğu haklar ekseninde tartışan Tom Regan (2004), "bir yaşamın öznesi olma" ölçütünü esas alır. Yaşamın öznesi olma fikri önemlidir; çünkü ahlaki aynıllı̆ımızı ve eşitliğimizi açıllar. Bir yaşamın öznesi olarak hepimiz aynıyızdır; çünkü bize ne olduğu (bedenlerimize, özgürlügü̈müze ya da hayatlarımıza) herhangi biri bunu önemsese de önemsemese de bizim için önemlidir (Regan, 2004, s. 51). Farklılıklarımız ne olursa olsun, bunlar temel benzerliklerimizdir. Bu nedenle bir yaşamın öznesi olan tüm canlıların hakları vardır (Regan, 2004, s. 53-54). Bu haklara (yaşam, özgürlük ve beden bütünlüğü) sayg1 duyma yükümlülüğ̈̈, öz farkındalıktan ve kapasitelerden bağımsızdır. Dolayısıyla hayvanların da insanlar için iyi ve faydalı olmaktan bağımsız bir değere ve bu değeri korumak için de haklara sahip olmaları ahlak yasasına uygundur (Regan, 2004, s. 53-57). Bu ahlaki yasanın geniş kapsamlı sonuçları ve yükümlülükleri vardır. Özellikle savunmasız topluluk üyelerinin (çocuklar, engelliler, yaşlılar ve yoksullar gibi) hakları ihlal edildiğinde, yapılan yanlışı anlayanların müdahale etme ve mağduru savunma görevleri vardır. İnsanlar haklarını ne kadar az savunursa, bizim bunu onlar için yapma görevimiz o kadar büyük olur (Regan, 2004, s. 41-42). Bu bağlamda büyük hayvan endüstrilerinde akıl almaz acılara maruz kalan milyonlarca hayvanın haklarının savunulması da ahlak yasasına uygun bir görevdir (Regan, 2004, s. 61).

Doğayla ilişkilerimizi düzenlemek adına eylemlerimize rehberlik edecek "çevre merkezci" ve "canlı merkezci" bu yaklaşımlar, makro düzeyde sosyo-politik kararların alınmasına da etik temeller sağlayacaktır. Bu kararlar, dünyadaki çevre sorunlarında büyük ölçüde payı olan sanayileşmiş ülkeler için olduğu kadar gelişmekte olan ülkeler ve Kırgızistan toplumu için de çevresel yıkımı önlemeye yönelik adımların atılmasına ve yeni çevresel yönetim biçimlerinin gelişmesine katkı sağlayıcı olacaktır.

\section{Kırgızistan'da Çevre Sorunları}

Kırgızistan, bölgesel özelliklerine bağlı olarak önemli çevre riskleri barındırmaktadır. Orta Asya genelinde olduğu gibi Kırgızistan'da da birçok doğal afet türü yaşanmaktadır. Ayrıca, doğadaki değissimler nedeniyle tetiklenebilecek doğal felaketlerin ortaya çıma riski de yüksektir. Bunlar içerisinde nehir kıyllarında ve dağ yataklarında bulunan radyoaktif atıkların yol açtığı radyoaktif kirlenme, su ve toprak kirliliği gibi riskler bulunmaktadır (Umuraliyev, Hetagurova, Moura ve Nizamiyev, 2012, s. 29).

Su rezervlerinin azalması ve buna bağlı gelişen su mücadelesi de bölgeye özgü sorunlardan biridir. Sovyetler Birliği dönemindeki merkezi planlama, hidrokarbon bakımından zengin olan Kazakistan, Özbekistan, Türkmenistan ile mineraller açısından zengin olmasa da büyük su rezervlerine sahip olan Tacikistan ve Kırgızistan arasındaki ilişkilerde dengenin korunmasını mümkün kılmıştır. Sovyetler Birliğinin dağılmasıyla birlikte bu denge değişmiş ve su paylaşımı konusunda bazı sorunlar ortaya çıkmıştır (Korıtnıy ve Cerelina, 2010, s. 14). Su kitlğı ve devletlerin her birinin kaynakları kendi beklentileri doğrultusunda kullanma talebi, bölgedeki istikrarı ve ekolojik dengeyi etkiler hale gelmiştir (Ciltsov, 2017, s. 20).

Kırgızistan'da biyosfer süreçlerindeki en önemli etkilerden biri de orman ekosistemlerine aittir. Ormanlar sadece Kırgızistan'ın değil tüm Orta Asya bölgesinin çevresel istikrarını sağlamaktadır. Bu nedenle, Kırgızistan'daki orman alanlarının genişlemesi büyük önem taşımaktadır. Ormanlar, ekolojik refahın sürdürülmesinde, hayvanların tür çeşitliliğinin desteklenmesinde, akarsuların ve yaylaların korunmasında son derece önemlidir. Toprak kayması ve heyelan gibi tehlikeli doğal afetler konusunda da hayati öneme sahiptir (Toktoraliyev ve Attokurov, 2009, s. 9-11).

Kırgızistan'ın toplam alanının \% 4,3'ünü oluşturan orman ekosistemi çok hassastır ve ekolojik dengenin herhangi bir ihlalinden hızlıca etkilenmektedir. Günümüzde Kırgızistan'daki orman kaynaklarının önemli kısmı yok edilmiş ve korunmakta olanlar da yaşlanmaya başlamıştır (Turdiyev ve Alimova, 2013, s. 31). Orman ekosisteminin uğradığ1 zarara benzer şekilde kaçak avlanma da Kırgızistan'da biyoçeşitliliği olumsuz yönde etkilemektedir. Birçok canlı türü yok olma tehlikesiyle karşı karşıya kalmakta, hayvanların beslenmesi için verimli otlaklar sürekli azalmaktadır. Tarım alanlarının çoğu erozyona maruz kalmaya başladığı için topraktaki humus içeriği gittikçe azalmakta ve geniş arazi alanları bozulmaya yüz tutmaktadır (Turdiyev, 2011, s. 215).

K.C. Çevre Koruma ve Ormanclık Kurumu ile K.C. Birleşmiş Milletler Kalkınma Programı tarafindan yapılan bir analizde, Kırgızistan geri döndürülemez iklim değişikliğine geçiş açısından güvensiz olarak tanımlanmaktadır (Kovalenko, 2017, s. 229). İklim değişikliğine uyum için öncelikli alanların geliştirilmesi konusunda uzmanlar tarafından yapılan ön hesaplamalar, iklim değişikliğinin 2100 yılına kadar ülkede ekonomik zararın yanı sıra yaşam standartlarını ve biyo-çeşitliliği olumsuz yönde etkileyeceğini göstermektedir (Kovalenko, 2017, s. 229). 
Kırgızistan'da olumsuz çevresel etmenlerden biri de madencilikteki açık ya da kapalı şekilde uygulanan kazı ve işletme yöntemlerdir. Madencilikte sondaj ve patlatma işlemleri yapılmakta, hendekler açılmakta, büyük oranda ağır kimyasal reaktifler kullanılmaktadır. Tüm bunların doğal çevre üzerine olumsuz etkileri olmakta, vahşi hayvanların yaşam alanı, bununla birlikte yeraltı sularının ve akarsuların kimyasal bileşimi bozulmakta, toprak ve bitki tabakası tahrip edilmektedir (Altımışbayeva, 2014, s. 157).

Üstelik madencilik işletmelerinin olumsuz etkileri sadece hâlihazırda faaliyet gösteren kuruluşlarla da sınırlı değildir. Eskiden işletilmiş maden ocakları daha çok tehlike yaratabilmektedir (Altımışbayeva, 2014, s. 158). Kırgızistan'da bu şekilde birçok atık ve çöp yığını bulunmaktadır. Mayluu-Suu, Min-Kuş, Kacı-Say gibi yerleşim yerlerinde çok sayıda atık alan oluşmuştur. Bunlardan birçoğu uranyum üretim atı̆̆ı, bir kısmı da metallerin üretim atığıdır. Atıkların birikmesinde ve yığılmasında, gerçekleşme olasıllğı yüksek heyelanlar, sel veya toprak kayması gibi afetler dikkate alınmamıştır. Mevcut ve kapalı maden işletmelerinin atıkları, su kaynaklarına, şehir ve bölge sınırlarına yakın olmasının yanı sıra, doğal afetler (deprem, sel) nedeniyle ciddi bir tehlike oluşturmaktadır (Cumagulov ve Akmatova, 2013, s. 64).

Bu göstergeler Kırgızistan'ın zengin doğal kaynaklarına rağmen oldukça endişe vericidir. Bu konuda acil önlemlerin alınması gerekmektedir. Kırgızistan'da resmi olarak “Çevre Uzmanlı̆̆1 Enstitüsü” kurulmuş olmasına ve "Çevre Uzmanlığı" yasası 1999'da kabul edilmiş olmasına rağmen verimli ve etkili projeler hayata geçirilememiştir. Sosyo-ekonomik koşullar, çevre mevzuatının etkili bir şekilde uygulanmasını engellemektedir. Diğer taraftan yine ekonomik yetersizlikler bağlamında, ekolojik, demografik ve benzeri alanlarda oluşan tehditleri önlemeye yönelik eylem planlarına yeterli fon ayrılamamaktadır (Turdiyev ve Alimova, 2013, s. 31). Yasal önlemler konusundaki beklentilerin ve ekonomik fon eksikliginin yanı sira halkın doğayı korumada kayıtsız kalması nedeniyle de birçok ekolojik sorunun iyileştirilmesi gecikmektedir. Çevre eğitiminin ve farkındalığının güçlendirilmemesi, çevreye zarar vermeye yönelik tutumlara daha kolay yol açabilmektedir (Cumagulov ve Akmatova, 2013, s. 64).

Bu tartışmalar, sivil toplum örgütleri, aktivistler, politikacılar ve vatandaşlar tarafından artık daha fazla gündeme getirilmektedir. Çevre sorunlarına karşı farkındalık, bu aktörlerin olduğu kadar medyanın da sorumluluk alanına dâhildir. Medya, kamusal sorunların tanımlanmasında ve müzakere edilmesinde birincil aktör olmasının yanı sıra halkın çevre sorunları hakkında bilgi edinmesi için de temel bilgi kaynağıdır. Medyanın, bu sorunların sosyo-ekonomik, etik, yasal ve eğitimsel boyutlara sahip olduğunun farkına varılmasında potansiyel bir güç olması beklenmektedir. Bu bağlamda çalışmanın amacı, Kırgızistan basınının çevre sorunları hakkında halkı bilgilendirmedeki başarısını değerlendirmek ve gazetelerin ekolojik sorunlara ilişkin farkındalık yaratma sorumluluğuna dikkat çekmektir. Bu çerçevede araştırmada başlıca şu sorulara yanıt aranmıstır:

1. Gazete haberlerinde çevre sorunu olarak gündeme taşınan konular nelerdir?

2. Gazete haberlerinde çevre sorunu olarak çerçevelenen nedir?

3. Kamu ve ticari gazete mantı̆̆ı, sorunları farklı bir şekilde çerçevelendiriyor mu?

4. Haberler, çevre sorunlarının nedenlerine ve çözüm yollarına vurgu yapıyor mu?

5. Sorunların ele alınışı insan merkezli mi, çevre merkezli midir?

\section{Yöntem}

$\mathrm{Bu}$ araştırmada yöntem olarak betimsel içerik analizi kullanılmıştır. Haberlerin tematik içerikleri, basının çevre sorunlarını nasıl ele aldığını görebilmek için haberlerdeki çerçeveleme ile beraber analiz edilmiştir. İçerik analizi, birbirine benzer verileri, belirli kavramlar ve temalar etrafinda toplayarak, sistematik ve analitik bulgulara ulaşmayı hedefler (Çalık ve Sözbilir, 2014, s. 34). Bu sistematik bulgulardan hareketle, metin içeriklerinin açı/belirgin özelliklerinden belirgin olmayan içerik özelliklerine doğru çıkarımlar elde eder (Gökçe, 2006, s. 23). Çerçeveleme analizi de bu içeriklerin hangi "yorumlama şemaları" içine yerleştirildiğini bulgulayarak (Goffman, 1974, s. 24) medyanın belirli bir konudaki tutumunu ve farkındalık yaratma gücünü ortaya koymaya çalışır.

\section{Evren - Örneklem}

Araştırmada, Kırgızistan'ın tirajı en yüksek kamu gazetesi olan "Kırg1z Tuusu” ve tirajı en yüksek özel gazetesi olan "Süper İnfo" gazeteleri örneklem olarak seçilmiştir. Tirajlarının yüksekliği nedeniyle, bu gazetelerin kamuoyundaki algıyı etkileme gücünün yüksek olacağı varsayılmışır. Bu gazetelerin internet sitelerinde 1 Temmuz 2019 - 1 Temmuz 2020 tarihleri arasında yer alan çevre temalı toplam 103 haberin içerik analizi yapılmıştır. İncelenen gazetelerin bilgileri Tablo 1'de yer almaktadır: 
Tablo 1. Incelenen Gazetelerin Bilgileri*

\begin{tabular}{|c|c|c|c|c|}
\hline Gazeteler & Yayıncılık Türü & $\begin{array}{l}\text { Yayina } \\
\text { Başlama Yılı }\end{array}$ & Tiraj1 & Genel Yayın Politikası \\
\hline Kırgiz Tuusu & $\begin{array}{l}\text { Kamu } \\
\text { (haftada iki kez) }\end{array}$ & 1924 & $\begin{array}{l}\text { Temmuz 2019: } \\
5218\end{array}$ & $\begin{array}{l}\text { Ülkenin ilk ulusal gazetesi } \\
\text { (Devlet politikası, milli tarih, ekonomi, kültür } \\
\text { ve diğer konular) }\end{array}$ \\
\hline Süper İnfo & $\begin{array}{l}\text { Ticari } \\
\text { (haftalık) }\end{array}$ & 2002 & $\begin{array}{l}\text { Temmuz 2019: } \\
35375\end{array}$ & $\begin{array}{l}\text { Sloganı: Çağımızdan geri kalmayın! } \\
\text { Misyon: En güncel bilgileri okuyucuya } \\
\text { ulaștırmak. }\end{array}$ \\
\hline
\end{tabular}

* Veriler gazetelerin web sitelerinden Temmuz 2019 tarihinde alınmıştır.

\section{Veri Toplama Araçları}

Araştırmanın veri toplama sürecinde 1 Temmuz 2019 - 1 Temmuz 2020 tarihleri arasinda yer alan haberler, gazetelerin web siteleri üzerinden taranmıştır. Taramada "Krrgızistan-çevre", "ekoloji”," "doğa", "doğal

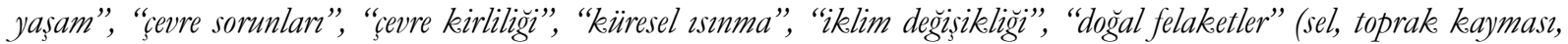
firtına, yangin), "madenler", "eko sistem", "biyo-çessitlilik" gibi anahtar kelimelerin kombinasyonu kullanılmıştır. Analize dâhil edilen haber içerikleri kategoriler içinde gruplandırılarak temalara ayrılmış ve bu doğrultuda kodlama yönergesi oluşturulmuştur. Kodlama yönergesinde mesajın bütünlüğünü belirli kategorilere indirgeme riskine düşmemek için bu kategorilerin, "bomojen olmasına", "bütünsellik tașımasına" ve "birbirini içermeyecek şekilde ayırt edici olmasına" dikkat edilmiştir (Bilgin, 2014, s. 12-14). Tematik içeriklerin oluşturulmasından sonra, güvenirliğin sağlanması için veriler, farklı zaman aralıklarında araştırmacı tarafindan yeniden kodlanmış ve kodlamalar arasında uyumsuzluk olan kategoriler revize edilmiştir. Daha sonra haberlerin nasıl çerçevelendiğini bulgulamak için haberin hangi kavramlar ve yorumlar etrafinda işlendiği analiz edilmiştir. Bu yorum çerçevelerinin belirlenmesinde Özarslan'ın (2007, s. 62-63) medya metinlerinde hakim olduğunu tespit ettiği haber çerçeve kategorileri ile Güz ve Saray'n (2016, s. 145-146) araştırmalarında tespit ettikleri haber çerçeveleri referans alınmıstır.

\section{Verilerin Analizi}

Haber içeriklerinin temalara ayrılmasıyla oluşturulan kodlama yönergesi ile haberlerin kavramsal ve bağlamsal yorum şemalarının kodlandığ çerçeve kategorilerinden elde edilen veriler Microsoft Excel çalışma sayfasına işlenmiş, Excel sayfası verileri SPSS programı kullanılarak analiz edilmiş ve verilerin frekansları hesaplanmıştır. Niceliksel verilerin sunumu haber içeriği özetleri ile desteklenmiştir.

\section{Bulgular}

Araştırmanın amacı doğrultusunda öncelikle incelenen gazetelerin ve haberlerin sayısal dağılımı belirlenmiş, daha sonra haber içeriklerinde ele alınan konular tematik içeriklere göre sınıflandırılmıştır. Haberlerin gazetelere ve aylara göre dağılımı Tablo 2'de sunulmaktadır.

Tablo 2. Incelenen Gazeteler ve Haberlerin Aylara Göre Dă̆ğlımı

\begin{tabular}{|c|c|c|c|c|c|c|c|}
\hline \multicolumn{4}{|c|}{ Kirg1z Tuusu } & \multicolumn{4}{|c|}{ Süper İnfo } \\
\hline 2019 & $\mathbf{N}$ & 2020 & $\overline{\mathbf{N}}$ & 2019 & $\mathbf{N}$ & 2020 & $\mathbf{N}$ \\
\hline Temmuz & 1 & Ocak & 5 & Temmuz & 2 & Ocak & 17 \\
\hline Ağustos & 3 & Şubat & 3 & Ağustos & 3 & Şubat & 2 \\
\hline Eylül & 3 & Mart & 2 & Eylül & 3 & Mart & 3 \\
\hline Ekim & 1 & Nisan & - & Ekim & 7 & Nisan & 4 \\
\hline Kasım & 8 & May1s & - & Kasım & 2 & Mayıs & 10 \\
\hline Aralık & 9 & Haziran & 2 & Aralık & 4 & Haziran & 9 \\
\hline Toplam & 25 & & 12 & & 21 & & 45 \\
\hline \multicolumn{5}{|c|}{$37(\% 35,9)$} & \multicolumn{3}{|c|}{$66(\% 64,1)$} \\
\hline
\end{tabular}

Tablo 2'deki verilere bakıldığında haberlerin \%35,9'unun Kırgiz Tuusu, \%64,1'inin Süper İnfo gazetesinde yer aldığ1 görülmektedir. Nisan-Mayıs aylarında Kırgız Tuusu gazetesi koronavirüs pandemisi (COVID-19) nedeniyle yayınlanmadığı için bu tarihler arasında haber yer almamıştır. 


\section{Haberlerde Ele Alınan Konular (Tematik İçerikler)}

İncelenen haberlerde çevre sorunlanna ilişkin konular çeşitlilik göstermektedir. Haber içeriklerinde ana temayı destekleyen alt temalarla birlikte çok katmanlı bir anlatı yapısı dikkat çekmektedir. Bu nedenle tematik olarak birden fazla kategoriye yerleştirilebilir olan haberlerde çoklu kodlama yapilmıştır. Kodlama sürecinde benzer içerikli kategoriler birleştirilmiş, geniş kapsayıcıllğı olanlar ise yeniden alt kategorilere ayrılmıştır. Haberde ele alınan konular Tablo 3’te sunulmaktadır.

Tablo 3. Çevre Haberlerinin Konulara Göre Dağzlımı

\begin{tabular}{|c|c|c|c|c|}
\hline \multirow{3}{*}{ Tematik İçerikler } & \multicolumn{4}{|c|}{ Gazeteler } \\
\hline & \multicolumn{2}{|c|}{ Kırg1z Tuusu } & \multicolumn{2}{|c|}{ Süper İnfo } \\
\hline & f & $\%$ & f & $\%$ \\
\hline Doğal afetler & 4 & $\overline{5,6}$ & 29 & 33,3 \\
\hline Nesli tükenmekte olan hayvanları koruma & 12 & 16,7 & 10 & 11,5 \\
\hline Eko yönetim çalışmaları & 12 & 16,7 & 8 & 9,2 \\
\hline Hava kirliliği & 7 & 9,7 & 8 & 9,2 \\
\hline Ekolojik sorunlara bağlı sağlık sorunları & 7 & 9,7 & 4 & 4,6 \\
\hline Aktivistlerin ve uzmanların uyarıları & 4 & 5,6 & 5 & 5,7 \\
\hline Madenlerin yol açtı̆̆ çevre sorunları & 4 & 5,6 & 5 & 5,7 \\
\hline Çevre sorunlarına ilişkin yasa tasarıları & 5 & 6,9 & 3 & 3,5 \\
\hline Yasal ve yasa dişı avlanma & 5 & 6,9 & 3 & 3,5 \\
\hline Çevre kirliliği & 3 & 4,1 & 5 & 5,7 \\
\hline Çevre ile ilgili cezai yaptırımlar & 3 & 4,1 & 3 & 3,5 \\
\hline Su kaynaklarının azalması & 2 & 2,8 & 2 & 2,3 \\
\hline Küresel 1sınma, iklim değişikliği & 1 & 1,4 & 2 & 2,3 \\
\hline Çevre farkındalığ1 organizasyonları & 2 & 2,8 & 0 & 0 \\
\hline Nükleer enerji santrali & 1 & 1,4 & 0 & 0 \\
\hline Toplam & 72 & 100 & 87 & 100 \\
\hline
\end{tabular}

Çevre sorunlarının gazetelerde gündeme gelme sıklı̆̆na bağlı olarak 15 tematik kategori tespit edilmiştir (Tablo 3). Bu sorun kategorilerinin yoğunluğu gazetelere göre benzerlik göstermektedir. Her iki gazetede de tematik içeriklerin ortak olarak "nesli tükenmekte olan hayvanları koruma", "eko-yönetim çalışmaları" ve "hava kirliliğ̀i" konularına odaklandığı görülmektedir.

"Nesli tükenmekte olan hayvanları koruma" içerikli haberlerde biyo-çeşitliliğin azalması sorunu, yasadışı avcıllk ve av turizmi sorunu gündeme gelmiştir. "Eko yönetim tedbirleri’" kapsamında; ekolojik diplomasinin geliştirilmesi, yeşil ekonomi projeleri, çevreci teknolojiler, maden işletmelerinin denetlenmesi ve çevre sorunlarının iyileştirilmesine yönelik finansal ihtiyaçlar ele alınmıştır. Kırgızistan'da son 2 yıldır sıkça gündeme gelen "hava kirliliğ̣”" sorunu kapsamında da özellikle çarpık kentleşme/düzensiz yapılaşma, kömür kullanımı ve araç sayısının fazlalığı gibi nedenlere dikkat çekilmiştir.

İki gazetenin tematik farklılıkları açısından bakıldığında ise doğal afetler Süper İnfo gazetesinde daha fazla gündeme taşınan konu (\%33.3) olmuştur. Doğal afet haberleri (sel, firtına, toprak kayması, yangın) çoğu zaman fiziksel hasar ve can kaybı verilerinin paylaşılması ile sınırlı kalmıştır. Bu haberlerin neredeyse tamamında yaşanan doğal afetler ile iklim değişikliği/küresel ısınma arasında bir ilişki kurulmamıştır.

Kırgız Tuusu gazetesinde çevre tahribatına ve hava kirliliğine bağlı olarak artan sağlık tehditlerine (kanser vakalarının ve engelli doğumların artması) görece daha fazla yer verilmiştir. Aynı şekilde "çevre sorunlarına ilişkin yasa tasarıları" ve bu bağlamdaki tartısmalar da Kırgız Tuusu gazetesinde daha fazla yer almıştır. Bu kapsamda, yasa tasarılarının meclise sunulması, uzlaşmaya varılamadı̆̆ için meclisten geçmeyen yasa taslakları ve bununla ilişkili yönetimsel eleştirilere yer verilmiştir.

En az gündem konusu olan çevre sorunlarının ise her iki gazetede de "madenlerin yol açtığ çevre sorunları" (radyoaktif atıkların zararları, kirli sular, besi hayvanlarının zarar görmesi vb.), "çevre kirliliğ̣", "çevreyi koruma önlemleri kapsamındaki cezalar", "su kaynaklarının azalması", "küresel 1sınma, iklim değişikliğ̣”" ile "çevre farkındalığı organizasyonları, hayırsever faaliyetler" olduğu tespit edilmiştir. 


\section{Haber Çerçeveleri}

Analizde haber çeşitliliği kavramsal çerçevesi kullanılarak gazetecilerin haber metinlerinde çoklu ve eleştirel bakış açılarını nasıl kullandıkları tespit edilmeye çalışılmışıı. Haber anlatısı içinde hâkim çerçeveye eklemlenen yan çerçeveler de olduğu için çerçevelerin belirlenmesinde çoklu kodlama yapılmıştır. Çerçeveler, metinlerdeki temalar, metinlerarasillk ve sözcüksel seçimler gibi söylemsel özelliklerin incelenmesi yoluyla belirlenmiştir. Çevre sorunlarının işlendiği bu çerçeveler Table 4'de yer almaktadır.

Tablo 4. Cevre Sorunlarmın Ișslendiği Haber Cerçeveleri

\begin{tabular}{lcccc}
\hline \multirow{2}{*}{ Haber Çerçeveleri } & \multicolumn{3}{c}{ Gazeteler } \\
\cline { 2 - 5 } & \multicolumn{2}{c}{ Kırgız Tuusu } & \multicolumn{2}{c}{ Süper İnfo } \\
\cline { 2 - 5 } & $\mathbf{f}$ & $\mathbf{0}$ & $\mathbf{f}$ & $\mathbf{\%}$ \\
\hline Ekonomi Politik Çerçeveler & 20 & 44,4 & 11 & 40,8 \\
\hline Risk/Tehdit Çerçeveleri & 13 & 28,9 & 6 & 22,2 \\
\hline Sorumluluk Çerçeveleri & 8 & 17,8 & 4 & 14,8 \\
\hline Yasal ve Hukuki Çerçeveler & 4 & 8,9 & 6 & 22,2 \\
\hline Toplam & $\mathbf{4 5}$ & $\mathbf{1 0 0}$ & $\mathbf{2 7}$ & $\mathbf{1 0 0}$ \\
\hline
\end{tabular}

Gazetelerde haberlerin hangi temalar ve yorumlar çerçevesinde işlendiğine baktığımızda; "ekonomipolitik çerçeveler", "risk/tehdit çerçeveleri", "sorumluluk çerçeveleri" ve "yasal ve hukuki çerçeveler" olmak üzere 4 farklı çerçeve tespit edilmiştir (Tablo 4). "Ekonomi-politik çerçeveler", çevre sorunlarının ekonomik ve politik sonuçlarını ve bu yöndeki girişimleri içermektedir. "Risk/tehdit çerçeveleri", çevre sorunlarının kısa ve uzun vadedeki olası risklerine vurgu yapmaktadır. "Sorumluluk çerçeveleri", çevre sorunlarının nedenlerini ve bu sorunları çözme sorumluluğunu belirli kişi ve kurumlara yüklemekte, görece eleştirel bir bakış açısı ortaya koymaktadır. "Yasal ve hukuki çerçeveler" ise çevre sorunları ile mücadelede hukuksal yaptırımların belirlenmesi ve uygulanması üzerinde durmaktadır.

İncelenen her iki gazetede de "ekonomi politik çerçeveler"in daha fazla olduğu görülmektedir. Bunun yanı sıra Kırgız Tuusu gazetesinde "risk/tehdit çerçeveleri”" de yüksek orandadır. Süper İnfo gazetesinde "risk/tehdit çerçeveleri" ile "yasal/hukuki çerçeveler" eşit orandadır. Kırgız Tuusu gazetesinde en az "yasal/hukuki” konular çerçevelenirken, Süper İnfo gazetesinde "sorumluluk çerçeveleri”" en düşük orandadir.

İncelenen toplam 103 çevre haberi içinde bu 4 çerçeveye dâhil olmayan haberler de vardır. Enformasyon içeriğinin belirli bir tema ve yorum bağlamında işlenmediği, olgusal ve yüzeysel olarak aktarıldığı bazı haberler, bu 4 çerçeveye dâhil edilmemiştir. Sözgelimi Süper İnfo gazetesinde doğal afetler en fazla (\%33.3) gündeme taşınan konu olmuştur. Ancak bu haberlerin içeriği, 2-3 satırdan oluşan yüzeysel bilgilerin; fiziksel hasar ve can kaybı verilerinin paylaşılması ile sınırlı kalmıştır. Doğal afetler ile küresel ısınma ve iklim değişikliği arasında ilişki kurulmamışır. Benzer şekilde yine Süper İnfo gazetesinde hava kirliliği içerikli haberlerin çoğunda kısa ve yüzeysel bir şekilde sadece hava kirliliği ölçümlerine yer verilmiştir. Dolayısıyla bu tür haberler çerçeve kategorilerine dâhil edilmemiştir.

Bu durumda Süper İnfo gazetesinde daha fazla sayıda çevre haberi olmasına rağmen, daha çok olaylar ve durumlar öne çıkarıldığ için daha az tematik çerçeve tespit edilmiştir. Olaya dayalı anlatımlarda (epizodik çerçeveleme), günlük olaylar ve durumlar yüzeysel olarak ele alındığı için, olaya ilişkin geniş toplumsal bağlam kurulmamaktadır. Kırgız Tuusu gazetesinde ise daha az sayıda haber olmasına rağmen, haberler geniş toplumsal bağlam içinde işlendiği için daha fazla tematik çerçeve tespit edilmiştir. Dolayısıyla sorun alanları ve çözüm yolları daha fazla vurgulanmış, haber akışı içinde diğer olaylarla bağlantı kurularak konuya düşünsel derinlik katılmıştır. Aşağıda bu dört ana çerçevenin gazetelere göre dağılımına ve genel haber içeriği özetlerine yer verilmiştir.

\section{Ekonomi Politik, Cerçeveler}

$\mathrm{Bu}$ çerçeve kapsamındaki haberler, çevre sorunlarının ekonomik ve politik sonuçlarına ve bu eksendeki çözüm girişimlerine odaklanmaktadır. Gazetelerde bunlar genel olarak, "biyo çeşitliliği korumaya yönelik çalışmalar", "eko yönetim çalışmaları", "devlet yetkilileri tarafindan madenlerin denetlenmesi" ve "çevre projelerine yönelik bütçe tahsisi” içerikli haberlerdir. Ekonomi Politik Çerçeveler kapsamında işlenen haber konuları Tablo 4.1'de yer almaktadır. 
Tablo 4.1. Ekonomi Politik Çerçeveler

\begin{tabular}{lllll}
\hline \multirow{2}{*}{ Ekonomi Politik Çerçeveler } & \multicolumn{3}{c}{ Gazeteler } \\
\cline { 2 - 5 } & \multicolumn{2}{c}{ Kırgız Tuusu } & \multicolumn{2}{c}{ Süper İnfo } \\
\cline { 2 - 5 } & $\mathbf{f}$ & $\mathbf{0}$ & $\mathbf{f}$ & $\mathbf{\%}$ \\
\hline Biyo-çeşitliliği korumaya yönelik çalışmalar & 9 & 45 & 4 & 36,3 \\
\hline Eko yönetim çalışmaları & 8 & 40 & 3 & 27,3 \\
\hline Devlet yetkililerinin madenleri denetlemesi & 2 & 10 & 3 & 27,3 \\
\hline Çevre projelerine yönelik bütçe tahsisi & 1 & 5 & 1 & 9,1 \\
\hline Toplam & $\mathbf{2 0}$ & $\mathbf{1 0 0}$ & $\mathbf{1 1}$ & $\mathbf{1 0 0}$ \\
\hline
\end{tabular}

Kırgız Tuusu gazetesinde "ekonomi politik çerçeveler" kapsamında, "biyo-çeşitliliği koruma çalışmaları" (\%45) ile "eko yönetim çalışmaları" (\%40) en fazla yer alan haber konularıdır. Süper İnfo gazetesinde ise çevre projelerine yönelik bütçe tahsisi (\%9.1) dışındaki konuların dağılımı birbirine görece yakın orandadır (Tablo 4.1).

Bu konuların haber içeriklerine baktığımızda; biyo çeşitliliği korumaya yönelik haberlerde, nesli tükenmekte olan hayvanların (kar leoparı, dağ keçileri, maral) güvenliği için alınan önlemler (KT 16.08.2019, KT 26.11.2019, KT 10.01.2020), avcıların yaraladığı kar leoparlarının tedavi ve rehabilitasyonu (KT 17.01.2020, 07.05.2020; SP 11.01.2020; 07.04.2020) konuları öne çıkmaktadır.

Eko yönetim çalışmalanna yer verilen haberlerde, devlet düzeyindeki yeşil ekonomi girişimleri (KT, 25.10.2019), ekolojik diplomasinin geliştirilmesi (KT, 12.11.2019), hava kirliliğinin önüne geçmek için yeşil ekonomiye dayalı projeler (KT, 17.12.2019; KT, 28.02.2020), orman eko sisteminin geliştirilmesi, maden atıklarını ve radyasyon zararlarını ortadan kaldırmak için planlanan projeler (KT, 25.02.2020), çevreye zararlı plastik poşet kullanımının engellenmesi için milletvekillerinin teklifleri (SP, 03.10.2019; 11.12.2019) gibi konular gündeme gelmiştir.

Madenlerin çevre güvenliği açısından gündeme geldiği haberlerde; madenlerin denetlenmesi ve ekolojik taleplere uymaları için ikaz edilmeleri (KT, 09.07.2019; SP,15.08.2019), maden ocaklarında meydana gelen kazaların ve ölümlerin araştırılması, madenlerin yasal ve ekolojik kriterler doğrultusunda çalıştırılması (KT, 18.12.2019), maden şirketlerinin ülke ekonomisine faydaları ve altın işletiminde ekolojik olarak en az zararlı yolların denenmesi (SP, 25.07.2019) gibi konular üzerinde durulmuştur.

Çevre sorunlarının çözümüne yönelik bütçe ihtiyacı haberlerinde ise hükümetin ekolojik durumu iyileştirmek için gerekli finansal kaynağı bulma girişimleri (KT, 31.01.2020) ile halka temiz su ulaştırılması için ödenek ayrılması (SP, 09.09.2019) konuları gündeme gelmiştir.

\section{Risk/Tehdit Cerçeveleri}

Bu çerçeve kapsamında işlenen çevre sorunları, kısa ve uzun vadede ortaya çıkması öngörülen çeşitli risklere atıfta bulunmaktadır. Bu riskler, hastalıkların artması, yasa dışı avcılık, madenlerin yol açtı̆̆ ekolojik tahribat, su kaynaklarının tükenmesi ve iklim değişikliği gibi haber içeriklerinde karşımıza çıkmaktadır. Risk/Tehdit Çerçeveleri kapsamında işlenen haber konuları Tablo 4.2'de yer almaktadır.

Tablo 4.2. Risk/ Tehdit Cerçeveleri

\begin{tabular}{llccc}
\hline \multirow{2}{*}{ Risk/Tehdit Çerçeveleri } & \multicolumn{3}{c}{ Gazeteler } \\
\cline { 2 - 5 } & \multicolumn{2}{c}{ Kırgız Tuusu } & \multicolumn{2}{c}{ Süper İnfo } \\
\cline { 2 - 5 } & $\mathbf{f}$ & $\mathbf{0}$ & $\mathbf{f}$ & $\mathbf{\%}$ \\
\hline Çevre ve hava kirliliğine bağlı sağlık riskleri & 4 & 30,7 & 3 & 50 \\
\hline Nesli tükenmekte olan hayvanların yok olması & 3 & 23,1 & 0 & 0 \\
\hline Madenlerin yol açt̆ğı çevre tahribatı & 3 & 23,1 & 0 & 33,3 \\
\hline İklim değişikliğine bağlı çevre tehditleri & 1 & 7,7 & 2 & 16.7 \\
\hline Su kaynaklarının azalması ve temiz su sorunu & 1 & 7,7 & 1 & 0 \\
\hline Nükleer enerji santrali tehdidi & 1 & 7,7 & 0 & $\mathbf{1 0 0}$ \\
\hline Toplam & $\mathbf{1 3}$ & $\mathbf{1 0 0}$ & $\mathbf{6}$ & \\
\hline
\end{tabular}


Tablo 4.2'de görüldüğ̈̈ üzere, çevre ve hava kirliliğine bağlı sağllk risklerinin gündeme geldiği haberlerde, çöp atıklarının çocuklarda alerji, astım gibi solunum rahatsızlıklarına yol açtığı (KT, 06.09.2019), hava kirliliğinden kaynaklanan hastalık ve ölüm sayılarının arttığı (bu verilere göre Kırgızistan'da onkolojik hastalıklar \% 23, engelli doğumlar ise \%64 artı̧̧ göstermiştir) (KT, 10.12.2019), Kırgızistan'da her yıl en az beş bin kişinin kansere yakalandığı ve yarım milyon kişinin akciğerlerinin hasta olduğu, bu sağlık sorunlarının önlenmesi için maden şirketi Centerra Gold ile anlaşma yapıldığı ve anlaşma kapsamında hükümete 10 milyon dolar tahsis edildiği, bunun 7 milyonunun onkolojik hastalıklar için verildiği (SP, 21.08.2019) konuları üzerinde durulmuştur.

Nesli tükenmekte olan hayvanların (kar leoparı, kulja, geyik, dağ keçisi) avlanmasının gündeme geldiği haberlerde; uzmanlar, aktivistler ve gazeteciler bu konuda yeterli önlemin alınmaması durumunda birçok türün kaybolma riski ile yüz yüze kalacağı konusunda uyarmaktadır (KT, 23.06.2019; 12.11.2019). Bu sorun Kırgız Tuusu gazetesinde toplumsal ve yasal çözüm önerileri bağlamında daha geniş çerçevede ele alınırken (KT, 25.02.2020) Süper İnfo gazetesinde olayların yüzeysel aktarımı ile sınırlı kalınmıştır.

Risk/Tehdit Çerçeveleri kapsamında öne çıkan bir diğer çevre sorunu da madenlerin yol açtı̆̆ ekolojik tahribattır. Bu kapsamdaki risklere sadece Kırgız Tuusu gazetesinde yer verilmiş, Süper İnfo gazetesinde ise yine olaylara ilişkin yüzeysel bilgilendirme ile sınırlı kalınmıştır. Kırgız Tuusu gazetesinde, Sulton-Sarı altın madeninin çevreye zarar verdiği, maden atık suları nedeniyle hayvanların zehirlenerek öldüğü, insan sağlığının zarar gördüğü ve maden yatırımcilarının bölgeyi terk etmeleri için birçok kez miting düzenlendiği bilgisine yer verilmiştir (KT, 09.08.2019). Maden ocaklarında meydana gelen kazalar ve ölümler de gündeme gelmiştir (KT, 18.12.2019).

Su kaynaklarının azalması sorunu da "risk/tehdit çerçeveleri" kapsamında işlenen bir konu olmuştur. Orta Asya'da ekolojik sorunların her geçen gün daha ciddi seyir gösterdiğini belirten bir haberde, Aral denizinin kuruması ana ekolojik problem olarak gösterilmiştir (KT, 05.11.2019). Su kaynaklarının azalmasına ilişkin Tarım Bakanlı̆̆ tarafindan bu yıl su kıtlı̆̆ yaşanacağına dair uyarıya da yer verilmiştir (SP, 03.05.2020). Risk/tehdit çerçevesi içinde en az karşılaşlan konulardan bir diğeri de küresel isınmaya bağl1 tehditlerdir. Bu konuyla ilgili dönemin Cumhurbaşkanı Ceenbekov'un açıklamasına yer verilen haberde; iklim değişikliğinin ekosistem ve insan hayatı için tehlikeli olduğu ve Kırgızistan'ın da iklim değişikliğinden etkilenecek bir ülke olduğu belirtilmiştir (KT, 12.11.2019). İklim değişikliği endişelerine yönelik dünyanın farklı bölgelerinden örneklerin verildiği haberler (SP, 13.01.2020; 14.02.2020) de gündeme gelmiştir.

Kazakistan ile Özbekistan arasında Nükleer enerji santralinin kurulması da risk/tehdit çerçevesinde işlenen bir haberdir (KT, 05.11.2019). Bu haberde Orta Asya halkının yeni bir ekolojik problemle karșı karşıya kaldığı, Çernobil Nükleer Enerji Santralindeki kaza hatırlatılarak kurulması planlanan santralin ciddi bir tehlike olacağı vurgulanmıştır.

\section{Sorumluluk Cerçeveleri}

Bu çerçevede işlenen haberler, çevre sorunlarının nedenlerini ve bu sorunları çözme sorumluluğunu belirli kişi ve kurumlara yüklemekte, eleştirel bir bakış açısı ortaya koymaktadır. Bu eleştirel tutumun işlendiği konular; yasa tasarılarının onaylanmamasına yönelik eleştiriler, hava kirliliğine yol açan kentleşme politikaları, çevre kirliliği ve maden işletmeleri konusunda yönetimlere yönelik eleştirilerdir. Sorumluluk Çerçeveleri kapsamında işlenen haber konuları Tablo 4.3'de yer almaktadır.

Tablo 4.3. Sorumluluk Cerçeveleri

\begin{tabular}{lcccc}
\hline \multicolumn{1}{c}{ Sorumluluk Çerçeveleri } & \multicolumn{3}{c}{ Gazeteler } \\
\cline { 2 - 5 } & \multicolumn{2}{c}{ Kırgız Tuusu } & \multicolumn{2}{c}{ Süper İnfo } \\
\cline { 2 - 5 } & $\mathbf{f}$ & $\mathbf{\%}$ & $\mathbf{f}$ & $\mathbf{\%}$ \\
\hline $\begin{array}{l}\text { Yasa tasarılarının onaylanmaması ve projelerin hayata geçirilememesi nedeniyle } \\
\text { yönetime yönelik eleştiriler }\end{array}$ & 2 & 25 & 2 & 50 \\
\hline Hava kirliliğine yol açan kentleşme politikaların eleştirilmesi & 2 & 25 & 1 & 25 \\
\hline Çevre kirliliği nedeniyle yönetimlerin eleştirilmesi & 2 & 25 & - & - \\
\hline Genel olarak insanlığın/sistemin eleştirilmesi & 1 & 12,5 & 1 & 25 \\
\hline Maden işletmelerine ve devletin bu yöndeki kararlarına yönelik eleştiriler & 1 & 12,5 & - & - \\
\hline Toplam & $\mathbf{8}$ & $\mathbf{1 0 0}$ & $\mathbf{4}$ & $\mathbf{1 0 0}$ \\
\hline
\end{tabular}


Yasa tasarısı sorumluluklarının vurgulandığı haberlerde; nadir bulunan hayvanların avlanmasını yasaklayan yasa tasarısının mecliste onaylanmaması (KT, 12.11.2019) ve ekolojiyi iyileştirmek için devlet düzeyinde ciddi projelerin hayata geçirilmemesi (KT, 31.12.2019; SP, 25.10.2019) konular1 daha çok milletvekillerinin ve aktivistlerin eleştirileri üzerinden gündeme gelmiştir.

Hava kirliliğine yol açan kentleşme politikalarının eleştirildiği haberlerde, belediyelerin arsaları yasa dışı satması, plansız yapılaşmanın doğal gaz, temiz su ve kanalizasyon erişimi sorununa yol açması (KT, 28.11.2019), şehirdeki ağaçların kitlesel bir şekilde kesilmesi ve çok katlı binaların inşa edilmesi (KT, 17.01.2020) ve ekoloji uzmanlarının hava kirliliğine yol açan yanlış uygulamalar karşısında sorumlu davranmaları gerektiği (SP, 17.10.2019) konularına dikkat çekilmiştir.

Çevre kirliliği nedeniyle hükümet ve yerel yönetimlerin eleştirildiği haberlerde de Isık Köl bölgesinin çöp atıkları nedeniyle turizm bölgesi olma özelliğini kaybedeceği endişesi (KT, 06.09.2019), Isık-Köl'ün içinden ve etrafindan üç tondan fazla çöp atığı toplandığ ve bu konuda yasa tasarısı çıkmadığı için umutsuz bir durumla karşı karşıya kalındığı (KT, 19.12.2019) belirtilmiştir.

Genel olarak insanllğın veya sistemin sorumlu tutulduğu haberlerde de Dünya Meteoroloji Örgütü’nün, küresel ısınma sorumlusu olarak insanlığın yanlış uygulamalarına atıfta bulunmas1 (KT, 06.08.2019) ve çevre aktivisti Great Thunberg'in Birleşmiş Milletler zirvesinde iklim değişimi tehdidi konusunda dünya liderlerini eleştirmesi (SP, 24.09.2019) konuları gündeme gelmiştir.

Sorumluluk Çerçeveleri içinde öne çıkan bir diğer eleştirel haber de maden işletmeleri konusunda devletin kararlarına yöneliktir. Haberde, maden işletmelerinin yol açtı̆̆ çevresel zararın, elde edilen ekonomik kazançtan çok daha fazla olduğuna (KT, 23.06.2020) dikkat çekilmiştir.

\section{Yasal ve Hukuki Cerçeveler}

Bu çerçeve kapsamında işlenen haberler, çevre sorunları ile mücadelede hukuksal bir rota belirlenmesi üzerinde durmaktadır. Bu hukuksal talepler; çevre sorunlarının çözümüne yönelik yasa tasarıları, yasak avlanmaya yönelik cezai yaptırımlar ve madenlerin askıya alınması gibi haber içeriklerinde karşımıza çıkmaktadır. Yasal ve Hukuki Çerçeveler kapsamında işlenen haber konuları Tablo 4.4'te yer almaktadır.

Tablo 4.4. Yasal ve Hukuki Cerceveler

\begin{tabular}{llccc}
\hline \multirow{2}{*}{ Yasal ve Hukuki Çerçeveler } & \multicolumn{3}{c}{ Gazeteler } \\
\cline { 2 - 5 } & \multicolumn{2}{c}{ Kırgız Tuusu } & \multicolumn{2}{c}{ Süper İnfo } \\
\cline { 2 - 5 } & $\mathbf{f}$ & $\mathbf{\%}$ & $\mathbf{f}$ & $\mathbf{\%}$ \\
\hline Çevre sorunlarının çözümüne yönelik yasa tasarısı çalışmaları & 2 & 50 & 3 & 50 \\
\hline Çevre kirliliğine ve yasak avlanmaya yönelik cezai yaptırımlar & 1 & 25 & 2 & 33,3 \\
\hline Madenlerin askıya alınması & 1 & 25 & 1 & 16,7 \\
\hline Toplam & $\mathbf{4}$ & $\mathbf{1 0 0}$ & $\mathbf{6}$ & $\mathbf{1 0 0}$ \\
\hline
\end{tabular}

Çevre sorunlarının çözümüne yönelik yasa tasarısı çalışmalarına yer verilen haberlerde, iklim değişikliğine ilişkin Paris anlaşmasının onaylanması (KT, 12.11.2019), çevre güvenliği hakları kapsamında uranyum ve toryum yataklarının araştırılmasını yasaklayan bir anlaşmanın imzalanması (SP, 16.12.2019; KT, 17.12.2019), Kırgızistan'ın Küresel Yeşil Büyüme Enstitüsüne katılımını amaçlayan bir yasa tasarısının mecliste oylamaya alınması (SP, 04.09.2019) konuları gündeme gelmiştir.

Gündeme gelen bir diğer konu da çevre kirliliğine ve yasak avlanmaya yönelik cezai yaptırımlardır. Bu yaptırımların gündeme geldiği haberlerde; Bişkek belediyesi tarafindan plastik ve çöp atı̆̆1 yakanların para cezasına çarptırıldığı (KT, 04.12.2019; SP, 05.12.2019) ve kar leoparını vuranlar hakkında ceza davası açıldığ1 (SP, 13.01.2020) bilgilerine yer verilmiştir.

Madenlerin askıya alınması ve cezai yaptırımların uygulanması kapsamında da Solton-Sarı altın madeninde Çin'den gelen yatırımcılar ile yerli halk arasında uzun süredir devam eden anlaşmazlık ve maden şirketinin faaliyetlerinin durdurulması gündeme gelmiştir (SP, 07.08.2019; KT, 09.08.2019). Haberlerde bu konuyla ilgili, halkın maden şirketine ekolojik kurallara uymadığı, yerli işçi yerine yabancı işçi çalıştırdığı gerekçesiyle karşı çıktığı bilgisine yer verilmiştir. 


\section{Haber Aktörleri}

İncelenen haberlerde, çevre sorunlarına ilişkin olay ve konularla ilgisi olan kişiler ile uzmanlık alanına ve kurumsal görevine göre fikirlerine başvurulan kişiler, haber aktörü olarak kodlanmıştır. Haber içeriklerinde habere konu olan aktör birden fazla olduğu için çoklu kodlama yapılmıştır. Haberlerde yer alan aktörler Tablo 5 'te yer almaktadır.

Tablo 5. Haber Aktörleri

\begin{tabular}{lcccc}
\hline \multirow{2}{*}{ Haber Aktörleri } & \multicolumn{3}{c}{ Gazeteler } \\
\cline { 2 - 5 } & \multicolumn{2}{c}{ Kirgız Tuusu } & \multicolumn{2}{c}{ Süper İnfo } \\
\cline { 2 - 5 } & $\mathbf{f}$ & $\mathbf{0}$ & $\mathbf{f}$ & $\mathbf{0}$ \\
\hline Ulusal kamu kurumları, kurumsal yetkililer & 20 & 23,8 & 12 & 19,4 \\
\hline Hükümet yetkilileri, bakanlar & 13 & 15,47 & 9 & 14,5 \\
\hline Milletvekilleri & 7 & 8,33 & 7 & 11,3 \\
\hline Yerel yönetimler & 7 & 8,33 & 4 & 6,5 \\
\hline Uzmanlar, bilim adamları & 7 & 8,33 & 3 & 4,8 \\
\hline Uluslararası kurumlar & 7 & 8,33 & 3 & 4,8 \\
\hline Halk/Vatandaş & 7 & 8,33 & 3 & 4,8 \\
\hline Sivil toplum örgütleri ve aktivistler & 4 & 4,76 & 6 & 9,7 \\
\hline Maden şirketleri/yatırımcıları & 4 & 4,76 & 4 & 6,5 \\
\hline Doğal afet mağdurları & - & - & 7 & 11,3 \\
\hline Cumhurbaşkanı & 2 & 2,38 & 2 & 3,2 \\
\hline Avcılar & 2 & 2,38 & 1 & 1,6 \\
\hline Çocuklar & 3 & 3,57 & - & - \\
\hline Maden işçileri & 1 & 1,19 & 1 & 1,6 \\
\hline Toplam & $\mathbf{8 4}$ & $\mathbf{1 0 0}$ & $\mathbf{6 2}$ & $\mathbf{1 0 0}$ \\
\hline
\end{tabular}

Tablo 5’te görüldüğü gibi habere konu olan aktörler iki gazetede de ağırlıklı olarak ulusal kurumlar/kurumsal yetkililer ve hükümet yetkilileridir. Devlet yetkilileri özellikle çevre sorunlarının sosyal ve ekonomik politikalar çerçevesinde işlendiği haberlerde, en fazla başvurulan bilgi kaynağı durumundadır. Aktörler kategorik olarak gruplandırıldığında, haber içeriklerinde politik aktörlerin yoğun bir şekilde yer aldığ1 görülmektedir. Bu aktörler karar alma ve uygulama süreci açısından politik ve yasal güce sahip kişilerdir. Halk, çocuklar ve işçiler ise ancak ölüm, yaralanma gibi doğal afet mağduru oldukları durumlarda haber aktörü olarak yer alabilmektedirler.

\section{Tartışma, Sonuç ve Öneriler}

Bu çalışma, tüm canlılar ve doğa için güvenli ve adil bir eko sistemin savunulması adına Kırgızistan basınında çevre sorunlarına ilişkin farkındalığı ve hâkim yorum çerçevelerini ortaya koymayı hedeflemiştir. Araştırmanın bulguları, Kırgızistan'da çevre sorunu olarak basına en yoğun yansıyan konuların, "nesli tükenmekte olan hayvanları koruma", "eko-yönetim çalşsmaları" ve "hava kirliliği" olduğunu göstermektedir. Çevre tahribatına ve hava kirliliğine bağlı olarak artan sağlık tehditlerine de (özellikle kanser, akciğer hastalıkları, engelli doğumların artması) yer verilmiştir. En az gündem konusu olan sorunlar ise "madenlerin yol açtı̆̆ çevre sorunlarr", "çevre kirliliği", "küresel ssınma", "iklim değişikliği” olmuştur. Çevre sorunlarına ilişkin tematik içerikler, ortalama olarak her iki gazete de benzerlik göstermektedir. Bu anlamda, gazetelerin yayın politikaları farklılıklarının, kamu ve ticari basın olmalarının haber içeriklerine çok fazla yansımadığı görülmektedir. İçeriklerde yer alan aktörlerin oransal dağılımı açısından da gazeteler arasında önemli farklliıklar yoktur. Haber çerçevelerinin de gazetelerin kamu ve ticari doğasıly çok az ilgisi olduğu görülmektedir.

Haber çerçeveleri, gerçekliğin temsiline rehberlik eden bilişsel yapılar olarak kabul edildiğinde; incelenen gazetelerin, çevre sorunlarına ait gerçekliğin bazı yönlerini ön plana çıkardığını ve bazı yönlerini göz ardı ettiğini söyleyebiliriz. İncelenen haberlerde tespit edilen çerçeveler, daha çok sorunları tanımlama işlevi görmektedir. Nedenlerin ve çözüm önerilerinin tanımlandığı çerçeveler azdır. Çevresel sorunlar ağırlıklı olarak ekonomik-politik sorunlar olarak çerçevelenmiştir. Ekonomi-politik çerçevelerin sık ve belirgin kullanımı, haberlerdeki çevre sorunları söyleminin doğasını yansıtmaktadır. Bu bağlamda 
haberlerde ağırlıklı olarak devlet politikaları öne çıkarılmaktadır. Risk ve tehdit çerçeveleri de sağlık sorunlarının ciddi bir şekilde arttı̆̆ına işaret etmektedir. Sorumluluk çerçeveleri kapsamında az sayıda eleştirel haber bulunmaktadır. Bu haberlerde yerel yönetimler, kentleşme politikaları eleştirilmekte, maden işletmeleri ile ilgili ekolojik sorunlar vurgulanırken ekonomik faydalar da hatırlatılmaktadır.

Çevre sorunlarına eleştirel çevre haberciliği perspektifinden yaklaşan az sayıda haberde ise çevre sorunları sosyal adaletsizlik ve eşitsizlikle ilişkilendirilmemiştir. Toplumda sosyo-ekonomik olarak avantajlı olanlara karşı dezavantajlı kişi veya durumlara ilişkin söylem üretilmemiştir. Oysa yönetimsel kararlar ve ekonomik olanaksızlıklar çevre sorunlarına neden olan etkenlerden biri olarak görülürken, dezavantajlı insanların da bu sistemin mağdurları olduklarının vurgulanması önemlidir. Yine bu doğrultuda haber içeriklerinde çevre sorunlarının coğrafi dağılımına veya bölgesel eşitsizliğe de vurgu yapılmamıştır. Hava kirliliğinin ve madenlerin yol açtı̆̆ sorunlar, bölgelere özgü farklı değişkenlere sahiptir. Ancak çevresel sorun türleri ile bu sorunlardan muzdarip bölgeler arasında bir ilişki kurulmamıştır. Haber çerçevelerinde eleştirel değerlendirmelerin zayıf olması, gazetelerin mevcut ekonomi-politik söylemle uyumlu bir yorum repertuarına sahip olduğunu göstermektedir.

Haberlerin bütünü açısından genelleştirildiğinde çevre sorunları antropojenik sosyo-ekonomik sorunlar olarak ele alınmıştır. İnsanın araçsal ve faydacı bir ilişki üzerinden çevreyi sömürme tutumu ve ekonomik fayda çabalarının çevre üzerindeki olumsuz sonuçları konusunda uyarıda bulunulmamıştır. Ekosistem ve doğanın kendisi (kirlenen nehirler, toprak, otlaklar vb.) hak sahibi ve mağdur olarak görülmemiştir. Nesli tükenmekte olan hayvanların mağduriyeti ise yaşam hakları ve özsel etik değerleri bağlamında değil, araçsal değerleri bağlamında, ülkeye kattıkları değer açısından vurgulanmıştır. Toplumsal algıyı ve sosyal politikaları dönüşüme uğratacak bir perspektif için mevcut ekonomik kalkınma söylemini sorgulayan, insan kadar doğanın ve insan dışı canlıların da yaşam haklarını savunan bir çevre haberciliğine ihtiyaç olduğu açıktır.

Yeryüzü insanın mülkiyet alanı değildir. Doğa, yıkıcı insan faaliyetlerine karşı belki çoğu zaman savunmasızdır ama tepkisiz değildir. Doğaya verilen zararlar, "gerçek" önlemler alınmadığı taktirde daha ciddi olumsuz sonuçlar doğuracaktır. İklim krizinin aciliyeti göz önüne alındığında insanlığın beslenme dahil tüm tüketim alışkanlıklarını ve değer algısını değiştirmesi gerektiği açıktır. Bu bağlamda öncelikle bitkisel beslenmeye geçişin insanlığın ve doğanın var olma mücadelesi açısından kritik bir öneme sahip olduğu bilinmektedir. Elbette makro ölçekli davranış değişimleri kolay değildir. Bu değişimleri insanların tercih ve vicdanlarına bırakmak da birçok sorun için geç kalmak anlamına gelebilir. Dolayısıyla politikanın merkezinde yer alan aktörler tarafindan yasal çalışmaların devreye girmesi ve projelerin hızlandırılması gerekmektedir. Çevre sorunları, bireylerin, sivil toplum kuruluşlarının, yerel yönetimlerin, hükümetlerin ortak çabaları, küresel aktörlerin ortak çaba ve girişimleriyle çözülebilir.

Sonuç olarak bu araştırmanın bulguları, analizi yapılan gazetelerin tasvir ettiği verilerle sınırlıdır. Çalısmanın bulguları çok daha geniş örneklem üzerinden ve çevre haberlerinin okuyucu kitle üzerindeki etkileri açısından da araştırılabilir. Sosyal medya mecraları giderek kamusal yaşamda aktif rol oynadığı için sosyal medya kullanıcıları üzerine de araştırmalar yapılmalıdır. Çevre sorunlarıyla ilgili tartışmaların genişlemesi, çevre etiği algısı ve sosyal politikalar üzerinde belirleyici olacaktır.

\section{Etik Beyan}

"Cevre Etiği Bağlammda Medyann Cevre Sorunlarna Yönelik Sorumluluğu: Kirgz̨istan Gazeteleri Örneğgı" başliklı çalışmanın yazım sürecinde bilimsel kurallara, etik ve alıntı kurallarına uyulmuş; toplanan veriler üzerinde herhangi bir tahrifat yapilmamış ve bu çalışma herhangi başka bir akademik yayın ortamına değerlendirme için gönderilmemiştir. Bu araştırmada doküman incelemesi yapıldığından etik kurul kararı zorunluluğu bulunmamaktadir.

\section{Kaynakça}

Alımışbayeva L. K. (2014). Ekologiçeskiye problemı v gornodobıvauşey promışlennosti Kırgızskoy Respubliki. İvestiya V uгov, 3, 157-159.

Attfield, R. (1991). The ethics of environmental concern. University of Georgia Press.

Bilgin, N. (2014). Sosyal bilimlerde içerik analizi. Ankara: Siyasal Kitabevi.

Cevizci, A. (2013). Uygulamalı etik. İstanbul: Say Yayınları.

Ciltsov S. S. (2017). Transgraniçnıye Vodnıye Resursı Tsentralnoy Azii: Ekologiçeskiy Aspekt. Materiyalı XIII mejdunarodnoy nauçnoy konferentsii. V 2-h çastyah. Pod redaktsiey A. V. Semenova, N. G. Malışeva, Y. S. Rudenko, 19-28. 
Cumagulov M. C. ve N. S. Akmatova. (2013). Osobennosti razvitiya ekologiçeskogo soznaniya v usloviyah sovremennogo Kirgizstana. Seriya Istoriya Filosofiya, 3(71), 64-67.

Çalık, M. ve Sözbilir, M. (2014). Parameters of content analysis. Ë̆itim ve Bilim, 39(174), 33-38.

De Jonge, E. (2016). Spinoza and Deep Ecology. Challenging Traditional Approaches to Environmentalism. London and NewYork: Routledge.

Des Jardins, J. R. (2013). Environmental Ethics. An Introduction to Environmental Philosophy. Boston:Wadsworth.

Devall, B. ve Sessions,G. (1985). Deep Ecology. Livins as if Nature Mattered. Utah: Gibbs Smith Publisher.

Evans, E. M., Schofer, E. ve Hironaka, A. (2000). Globally visible environmental protest: A cross-national Analysis, 1970-2010. Sociological Perspectives, 63(5), 786-808.

Ferry, L. (2000). Ekolojik yeni düzen (Çev. Turhan Ilgaz). İstanbul: Yap1 Kredi Yayınları.

Giddens, A. (2012). Sosyoloji (Yay. Haz: C. Güzel, Çev: H. Özel). İstanbul: Kırmızı Yayınları.

Goffman, E. (1974). Frame analysis: An essay on the organization of experience. Cambridge, MA, US: Harvard University Press.

Gökçe, O. (2006). İ̧erik analiži. Ankara: Siyasal Kitabevi.

Güz, N. ve Saray, G. (2016). Ak Parti hükümetlerinin nükleer enerji politikalarının türk basınında tartış1ması (20002016 Dönemi), bilig, 79, 129-158.

Korıtnıy L. M. ve İ. V. Cerelina. (2010). Mejdunarodnıye Reçnıye i Ozernıye Basseynı Azii: Konfliktı, Puti Sotrudniçestva. Geografiya i prirodnuye resursı, 2, 11-19.

Kovalenko O. V. (2017). K voprosu ob ekologiçeskoy situatsii v Kırgızskoy Respublike. Novaya nauka: Problemı i perspektiv1. Mejdunarodnoye naucnoye periodiceskoye iz̨daniye po itogam Mejdunarodnoy naucno-praktiçeskoy konferentsii (Perm, 26 yanvarya 2017) v 2 ç. C..2, Sterlitamak: AMİ, 1(2), 228-233.

Leopold, A. (1987). A land ethic. A sand county almanac. New York, Oxford: Oxford University Press.

Longo, S.B., Clausen, R. ve Clark, B. (2015). The Tragedy of the Commodity: Oceans, Fisheries and Aquaculture. New Brunswick, New Jersey, and London: Rutgers University Press. pp. 15-38.

Mutlu, B. (2020). Yeni aristotelesçi bir bakış açısıyla hayvanlar ve hayvanlığımız. Beytulbikeme An International Journal of Philosophy, 10(2), 511-580.

Naess, A. (1986). The deep ecology movement: Some philosophical aspects. Philosophical Inquiry, 8, 10-31.

Naess, A. (2008). The ecology of wisdom (Edt: A. Drengson ve B. Devall). Berkeley: Counterpoin

Drengson, A. (2008). Introduction in Drengson, A. and Devall, B. (ed.) The Ecology of Wisdom. Berkeley: Counterpoin.

Ortiz, R.J. (2020). Oil-Fueled Accumulation in Late Capitalism Energy, Uneven Development, and Climate Crisis. Critical Historical Studies. Volume 7 (2), 205-240.

Özarslan, H. (2007). Cerçeveleme yaklaşım açısından baber çerçevelerinin iə̣ler kitle düşünceleri üzerindeki etkisi (Doktora Tezi). Selçuk Üniversitesi, Sosyal Bilimler Enstitüsü, Konya.

Regan, T. (2004). Empty cages. Facing the challenge of animal rights. USA: Rowman \& Littlefield Publishers, INC.

Siebert, J. (2020). The greening of uneven and combined development: IR, capitalism and the global ecological crisis. Cambridge Review of International Affairs, 1-22.

Singer, P. (2005). Hayvan özgürleşmesi (Çev: H. Doğan). İstanbul: Ayrıntı Yayınları.

Singer, P. (2015). Pratik etik (Çev: N. Çatlı). İstanbul: İthaki Yayınları.

Smith, M. (2011). Against ecological sovereignty. Ethics, biopolitics, and saving the natural world. University of Minnesota Press.

Sparks, T., Kurki, V. ve Stucki, S. (2020). Animal rights: interconnections with human rights and the environment. Journal of Human Rights and the Environment, 11(2), 149-155.

Toktoraliyev B. A. ve Attokurov A. (2009). Ekologiçeskoye sostoyaniye lesov Kırgızstana. KTMÜ, Fen Bilimleri Dergisi Özel Sayz: 10, 9-15.

Tong, J. (2014). Environmental risks in newspaper coverage: A framing analysis of investigative reports on environmental problems in 10 Chinese newspapers. Environmental Communication, 8(3), 345-367.

Turdiyev T. İ. (2011). Sotsiyalnıye aspektı ekologo-ekonomiçeskoy situatsii v Kırgızstana. Sotsiyalnaya politikea $v$ sotsiyologiya, 2, 214-222.

Turdiyev T. İ. ve G. B. Alimova. (2013). Stanovleniye pravovogo gosudarstva v Kirgızstane: Regionalniy ekologoekonomiçeskiy aspekt. Vestnik KRSU, 13(12), 30-32.

Umuraliyev R., Hetagurova V. Ş., Moura R. ve Nizamiyev A. (2012). Tsentralnaya Aziya: Putin Snijeniya Riska Katastrof. Energiya: Ekonomika, Tehnika, Ekologiya, 12, 28-35.

\section{EXTENDED ABSTRACT}

In our age, environmental problems have reached threatening levels for all living things and nature. In case of not taking timely and effective measures, more serious vital problems await the world and concerns in this context increase. The arguments on the impact of environmental problems on our lives and how they can be improved are also expanding in parallel these concerns.

It is expected that the media will have a potential power in raising awareness of these problems and channeling environmental policies. For people's attitudes towards environmental problems can lead to potential social changes in order to minimize these problems. In fact, experiences in different parts of the 
world show that the more frequent environmental problems come to the agenda in the public sphere expand the social resistance movements (Tong, 2014; Evans, Schofer, \& Hironaka, 2000). It is important to strengthen awareness of environmental problems in the media in order to change Kyrgyz society to a society where environmental risks can be reduced. Based on this importance, this research examines how the environmental problems in Kyrgyzstan are reflected in the media and how environmental news is framed.

Within the scope of the analysis, "Kyrgyz Tuusu" which is the public newspaper with the highest circulation in Kyrgyzstan, and "Super Info", the private newspaper with the highest circulation, were selected as samples. Due to their high circulation, it was assumed that these newspapers would have a high potential to influence public debate. A content analysis of news on environmental problems published on the websites of these 103 newspapers between July 1, 2019 and July 1, 2020 was conducted. Thematic contents were analyzed together with the framing of the news in order to see how the press approaches environmental problems, and answers were sought for the following questions in this direction:

1. What are the issues brought to the agenda as an environmental problem in news?

2. What is framed as an environmental problem in news?

3. Does the apprehension of public and commercial newspaper frame the problems differently?

4. Does the news emphasize the causes and solutions of environmental problems?

5. Is the handling of problems anthropocentric or eco-centric?

The findings of the research shows that the most intensely reflected issues in the press as the environmental problem in Kyrgyzstan are "protection of endangered animals", "actions on ecomanagement" and "air pollution". Increasing health threats due to environmental damage and air pollution, especially cancer, lung diseases, and increased births with disabilities). The least of the issues on the agenda were "environmental problems caused by mines", "environmental pollution", "global warming", "and climate change". Thematic contents on environmental issues are similar, on average, in both newspapers.

It is seen that the differences in the publication policies of newspapers and being public and commercial media do not reflect much on their news contents. There are no significant differences among the newspapers in terms of the proportional distribution of the actors in the content. News frames also appear to have little to do with the public and commercial nature of newspapers.

When news frames are accepted as cognitive structures that guide the representation of reality, we can say that the analyzed newspapers highlight some aspects of the reality of environmental problems and ignore some of them. The frames determined in the news analyzed mostly serve to define the problems. Frames where causes and solutions are defined are few. Environmental problems are mainly framed as economic-political problems. The frequent and pronounced use of economic-political frames reflects the nature of the discourse on environmental problems in the news. In this context, state policies are predominantly emphasized in the news. Risk and threat frames also point to an increase in health problems. There is little critical news under "responsibility frames". In this news, local governments and urbanization policies are criticized, while ecological problems related to mining companies are emphasized, economic benefits are also reminded.

In the few reports in which environmental problems were handled critically, environmental problems were not associated with social injustice and inequality. No discourse has been produced regarding disadvantaged people or situations against those who are socio-economically advantageous. While administrative decisions and economic impossibilities are seen as one of the factors that cause environmental problems, it is important to emphasize that disadvantaged people are also the victims of this system.

There is no emphasis on the geographical distribution of environmental problems or regional inequality in the news content. Problems caused by air pollution and mines have different variables specific to regions. However, no relationship has been established between the types of environmental problems and the regions suffering from these problems. The weakness of critical evaluations in news frames shows that the newspapers have an interpretation repertoire in line with the current economicpolitical discourse.

Environmental problems are considered as anthropogenic socio-economic problems when they are generalized in terms of the whole news. There is no warning about the attitude of exploiting the 
environment through an instrumental and utilitarian relationship, and the negative consequences of economic benefit efforts on the environment. The eco-system and nature itself (polluted rivers, land, pastures, etc.) were not seen as victims. The victimization of endangered animals is not in the context of their right to life and ethical values; it is emphasized in terms of the value it adds to the country. It is clear that there is a need for news that questioning the current economic development discourse for a perspective that will transform social perception and social policies, that defend the right to life of nature and non-human creatures as much as humans. 